\title{
The Era of Society 5.0 as the unification of humans and technology: A literature review on materialism and existentialism
}

\section{Era Society 5.0 sebagai penyatuan manusia dan teknologi: Tinjauan literatur tentang materialisme dan eksistensialisme}

\author{
Melinda Rahmawati ${ }^{\bowtie}$, Ahmad Ruslan, \& Desvian Bandarsyah \\ History Education Study Program, Faculty of Teacher Training and Education, \\ Muhammadiyah University of Prof. Dr. Hamka \\ East Jakarta, 13830, Special Capital Region of Jakarta, Indonesia \\ E-mail of the corresponding author:melinda@uhamka.ac.id
}

\begin{abstract}
The Industrial Revolution 4.0 brings society in fast-paced change. Technology and social media emerge not only as a means of communication and accessibility of modern society, but also as a means of mass news spread and provocation. When society and technology coexist, technology is able to drive people to have accessibility without time limits. The objective of this study is to describe the overview of the Era of Society 5.0 seen from the perspectives of materialism and existentialism in social sciences. The research method used was descriptive qualitative with literature review analysis which specifically discussed modern society and the idea of materialism and existentialism. The results of this study showed that the Era of Society 5.0 has indeed become an era of the unification of humans and technology. Technology has become a necessity that must be fulfilled by all people. The perspectives of materialism and existentialism view it as a critical period because society is vulnerable to division if it is not directed properly. This study concluded that the Era of Society 5.0 is described as a period when humans and their mindsets are trapped between material needs and the desire for existence. Technology that is interconnected and accessed without limits presents a complex situation. The streams of materialism and existentialism provide an overview of the situation of society in two related sides.
\end{abstract}

Keywords: existentialism; modern society; materialism; society 5.0; technology

\begin{abstract}
Abstrak
Revolusi industri 4.0 membawa masyarakat dalam perubahan yang berjalan cepat. Teknologi dan media sosial bermunculan tidak hanya menjadi sarana komunikasi dan aksesibilitas masyarakat modern sekaligus menjadi sebuah sarana media penyebaran berita dan provokasi yang masif. Ketika masyarakat dan teknologi hidup berdampingan, teknologi mampu mendorong masyarakat untuk memiliki aksesibilitas tanpa batas waktu. Tujuan dari penelitian ini adalah untuk mengetahui gambaran Era Society 5.0 yang dilihat dari sudut pandang aliran materialisme dan eksistensialisme dalam ilmu sosial. Metode penelitian yang digunakan adalah kualitatif deskriptif dengan analisis studi pustaka yang secara khusus membahas mengenai masyarakat modern serta pemikiran materialisme dan eksistensialisme. Hasil penelitian ini menunjukkan bahwa Era Society 5.0 memang menjadi sebuah era penyatuan manusia dan teknologi. Teknologi telah menjadi sebuah kebutuhan yang harus dipenuhi oleh seluruh masyarakat. Pandangan materialisme dan eksistensialisme memandangnya sebagai sebuah masa kritis karena masyarakat rentan dengan perpecahan jika tidak diarahkan secara tepat. Studi ini menyimpulkan Era Society 5.0 tergambarkan sebagai masa saat manusia bersama pola pikirnya terjebak antara kebutuhan material dan keinginan eksistensi. Teknologi yang saling terhubung dan diakses tanpa batas menghadirkan sebuah situasi kompleks. Aliran materialisme dan eksistensialisme memberikan penggambaran situasi masyarakat dalam dua sisi yang berhubungan.
\end{abstract}

Kata Kunci: ekstistensialisme; masyarakat modern; materialisme; society 5.0; teknologi

\section{Introduction}

Society exists as a social system that moves dynamically according to the times. The challenges of change that are spreading in society from the Era of Industry 4.0 to the Era of Society 5.0 are impossible to be considered simple and easy to go through (Meindl et al. 2021, Nastiti \& Abdu 2020). Society has 
undergone a number of changes since the beginning of the development of industry 1.0 in Europe until it continues with the revolution 4.0 today. Together with the idea of sustainable development goals, it begins to develop a society that is integrated with technology. Competitive human resources with the presence of Artificial Intelligence (AI) encourage today's society to become an advanced society in terms of human resources and the use of technology.

Modern human actions are currently driven by developing knowledge and it transforms them into a knowledge society with social groups, social situations, social interactions, and social roles that depend on knowledge (Ritzer \& Smart 2018). The ability of humans to create a new technology from the outcomes of the development of their knowledge particularly makes modern humans always prioritize rational thinking alone. The problems encountered in the midst of modern society form a new problem that is much more complex and interrelated. One social group and another compete with each other for roles and fight for control of the situation so that their groups get respect in the eyes of the wider community. The developed knowledge has been able to make modern humans invent a technology that can facilitate various needs and community activities so that the technology that is present is no longer a new element in society. Technology is present as a necessity that is required to facilitate all activities of modern society nowadays.

The presence of technology today has helped bring convenience to modern human life. Thus, modern human needs for materials as demands that accompany these technologies also increase (Kariarta 2020). The development of modern society moves faster and technology changes along with it. The knowledge that drives all these advances bring about a social order and human civilization that is integrated with technology. Technology as the result of thinking from knowledge creates a new human civilization that makes humans do not need time to carry out any mobility activities, in which all can be done at one time together and in a short time. The accessibility of the community in carrying out activities will be maximized and easier only by capitalizing on technological aids that have been created by humans.

The technology that is currently developing is not only accompanied by the stream of materialism, the stream of thought which states that everything is directly related to matter, so that phenomena that occur are the result of interactions through materials. However, there is also existentialism, which is a stream of thought which states that humans are not only thinking subjects, but individuals who can carry out an action, who are able to feel, and live to create thoughts in them. Materialism is present due to needs that must be fulfilled, while existentialism is present due to dissatisfaction with situations that make humans have to think based on rationality to be able to create something that can regulate the universe (Ekawati 2017, Nakagawa et al. 2021, Salim 2010). People are massively competing to have a lot of material to fulfill their needs and desires for the latest technological devices that are present for their activities. Meanwhile, on the one side, the community continues to create new innovations that can support all the activities it does. The movement to have as much material as possible and the ability to innovate often drive people to become consumptive and think too rationally in producing work. Rational thinking is indeed required in designing and managing everything, but that does not mean that rational thinking is the most significant one (Jamwal et al. 2021, Kazancoglu et al. 2021). Likewise, for the material, the community needs money as a means of transaction to meet their needs. However, it does not mean that the money earned can be used to buy everything in the public.

The integration of society in the Era of Society 5.0 with technology will be seen from two different social views, including materialism and existentialism. For followers of materialism, the novelty of technology that exists today encourages society to have as much money as possible in various ways. It aims to fulfill their needs and desires. Money and materials owned are a benchmark of social class in society. Meanwhile, for existentialists, humans need rationality to regulate the universe. The universe is formed irregularly so that rational thinking is required to regulate it and create a device that can organize and maintain order in society. 
The objective of this study is to determine the character of the society that live in the Era of Society 5.0 where technology has become an inseparable part of human life. Technology that is present, developing, and renewable changes in terms of position from tertiary needs to primary needs (Beltrami et al. 2021, Sharma et al. 2021, Tabaa et al. 2020). Smartphones are present as a technology that must be owned by every individual whose usability function is adjusted to the user's needs. Financial transaction activities no longer need to go to the bank office directly, but can be carried out through the m-banking application, internet banking, E-Wallet, and the latest ATMs that provide cash deposit services. Similarly, in terms of accessibility of transportation, health, food, and all human needs, from primary to tertiary, all can be carried out with existing technology. Humans and technology have become inseparable units. However, when technology develops and changes position in the level of human needs as social beings, there are in fact some perspectives about it. Some that are significant include materialism and existentialism. These two perspectives accompany the shift in the use of technology as a primary need in society that influences society in this Era of Society 5.0.

This study limits the perspectives of materialism and existentialism to society in the Era of Society 5.0. When humans and technology coexist, humans definitely need efforts to meet the need for technology to facilitate all their activities. However, as a matter of fact, it changes the human paradigm with the argument that material is the main thing that humans have. Equally, from the standpoint of existentialism, humans have rational thinking and are able to create a culture that becomes human civilization. Humans are present as creators by creating something meaningful for all mankind and the universe. When humans are able to create, their creations will certainly be published to others. After it is published and many people are interested, they will obviously want to obtain it even though it costs a lot. This is what drives the establishment of a consumptive society. In truth, this is not the case. Material and existence are indeed needed to fulfill needs. If the needs have been fulfilled, humans will certainly reach the point of satisfaction and be able to control desires that are only temporary.

A study on the urgency of Society 5.0 was previously conducted by Mahmudi (2019), but this study focused specifically on the perspective of social theory, particularly from the paradigms of materialism and existentialism. These perspectives see changes in society in terms of material and existence. Materialism suggests that material is the main thing that must be fulfilled by society, meaning that people who are not able to fulfill their own material will be eliminated. Meanwhile, existentialism suggests that humans must be able to become creators in the social order. Without the power to create, humans will be left behind in the flow of change in the surrounding community. People who live in the Era of Society 5.0 will definitely be faced with various problems related to the social stratification of society and character competition in society in the Era of Society 5.0.

\section{Research Methods}

This study used descriptive qualitative research. This study took measures neither to change nor act subjectivity in the object of research. Qualitative studies take actions that are limited to presenting the overview in the object of research (Arikunto 2019). This study was conducted based on a literature review based on books and scientific articles. The present technology has turned into a general public need.

The findings of the study were analyzed using the social theory proposed by George Ritzer. The data triangulation in this study was carried out using methodological triangulation collected from document data and literature observations. The triangulation was performed as an effort to support and show the shape of the data size from the results of the research conducted. The literature data presented proved that the results of this study do not depend or contradict, but provide, prove, and see the occurrence of a potential cognitive conflict of interest (Miles 1992). In this study, the data were collected from various academic literature, web pages from trusted information media, and other research reports that specifically discuss society in the Era of Society 5.0 as a civilization when humans and technology coexist. 


\section{Results and Discussion}

\section{Society in the Era of industry 4.0 and Society 5.0}

The knowledge society does not exist by itself. Rather, a knowledge society is developed from complex problems in society and changes in society that starts to use technological communication methods to narrow the distance of communication between humans (Ritzer \& Smart 2018, Sallati \& Schützer 2021). The Industrial Revolution 1.0 has started a change in human civilization. When steam technology began to be developed to power machines in factories, people benefited from an increase in the number of products produced. At that time, people began to use steam engines to create many tools needed for their activities. More changes continued to emerge along with the impact of the world war which resulted in so many losses for both sides. Entering the Era of Industry 2.0, people created a number of heavy equipment that used electricity. Steam engines that are not environmentally friendly stirred people to create new inventions that are more effective, efficient, and environmentally friendly. However, there was still something missing. Mobilization of the community, particularly in the distribution of goods, has not been effective with horse-drawn carriages. Therefore, various means of transportation were created such as cars, trains, and other means of transportation. The Era of Industry 3.0 emerged at the end of World War II. The era of computerization started to run to store confidential data in the form of certain codes that could be accessed by particular systems. Computerization has been refined from a relatively large size to a small size as it is used today. The Era of Industry 4.0 emerged with more specific and complex changes. Computerization is a technology that is needed in various activities in society. Internet of Things (IoT) and Artificial Intelligence (AI) became the outcomes of modern human creation at that time which made access to information in 1 main data repository and it was integrated with various other accesses. In this Era of Industry 4.0, community skills are centered on 6C skills (Communication, Collaboration, Critical Thinking, Citizenship, Creativity, and Character). By carrying out another label as "the era of disruption" which presents a situation in which people switch to communicate using social media, disseminated information via social media, and the important role of social media in supporting the accessibility of today's modern society.

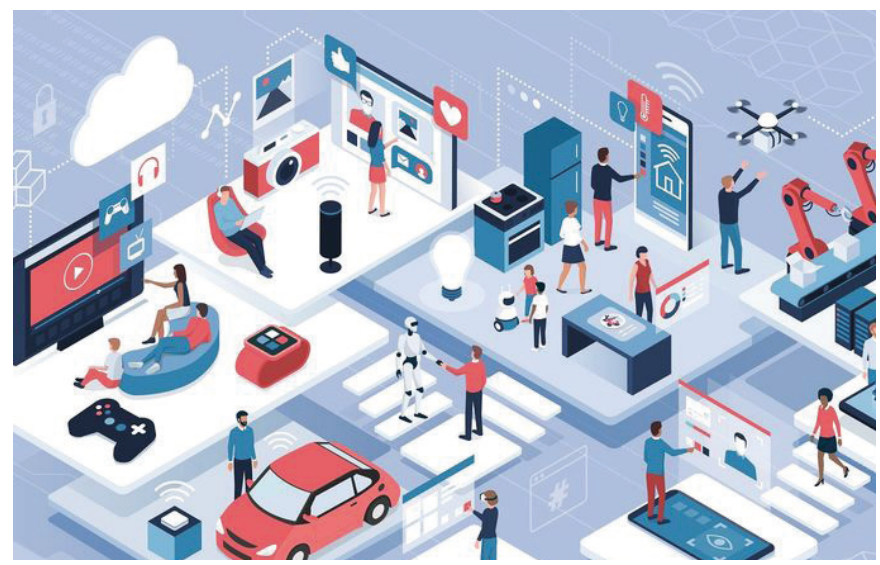

Figure 1.

Illustration of the implementation of technology in the Era of the Industrial Revolution 4.0 Source: Putri (2021)

The community carries out interaction and communication as the needs of social beings. The community as a unit establishes a social structure in accordance with the generally agreed will based on similarities between individuals or community groups (Koentjaraningrat 2015). Community interaction from Industry 1.0 to 4.0 which is currently moving is evidently different. Before the invention of computers and the internet, people communicated in simple ways such as by sending letters and telegrams. The accessibility was not effective because it took time to move from one place to another. Differences in location and mileage will also affect the required travel time. With the presence of computers and the 
internet that support community accessibility, people create a communication device in the form of hardware or software to support all human activities in society to be carried out quickly and efficiently. The obvious form that can be seen today is the number of smartphones that are produced with various advantages and a lot of software that both function as communication media, social media, and finance (m-banking \& internet banking). People in the Era of Society 5.0 will certainly be much more supported in terms of their accessibility with increasingly sophisticated technology and they able to fulfill all the mobility needs of modern society. As illustrated in Figure 1, the implementation of technology in daily activities in the current Era of Industrial Revolution 4.0 presents the convenience of beneficial mobility.

Another side of society as a unit is that there is a form of dependence in the development of the country (Budiardjo 2018, Soekanto 2015). Modernity and globalization have created a situation of dependence between developed and developing countries. Developing countries require various tools, medicines, and so on to fulfill the needs of their people. Meanwhile, developed countries need consumers who will use and buy their products. Fulfilling the needs between the two cannot be avoided and causes a dependency. Society in Industry 4.0 in developing countries try their best to move to adapt to society in Industry 4.0 in developed countries. The massive transition of public accessibility to virtual media and the use of online transactions has begun to carry out and the transition process has been accelerated. Society 5.0 is described to be more dynamic in its mobility movement than the society in this era of disruption. The use of smartphones with various advantages and software that functions to support all community activities is no longer a luxury good, but has become a secondary need that must be fulfilled by the community.

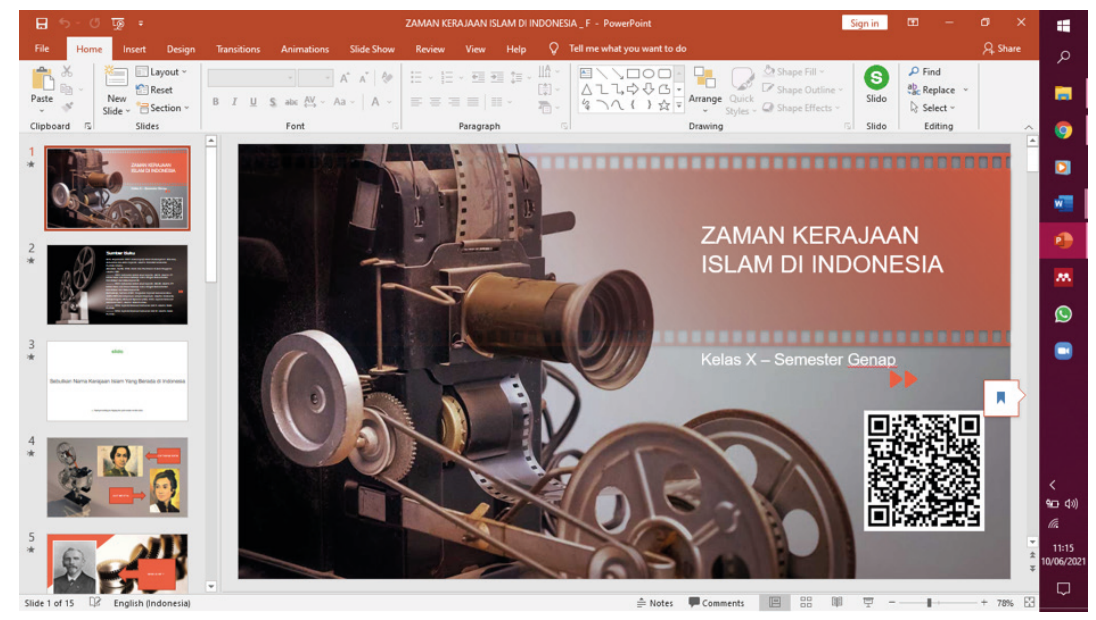

Figure 2.

Application of QR Code in the learning process

Source: Personal data

The industry of the future has come to accelerate the modernization of industrial tools. Industrial development as part of the spread of new technologies is not only limited to the simple expansion of sensors, robots, or innovative devices. Further, there is a form of encouragement to shape digitalization in the industrial sector. Digital technology and digitization are several forms of transformation that exist to revolutionize society in industrial models, changing structures, and interactions for outstanding business agility (Nagy \& Hajrizi 2019, Tabaa et al. 2020). The society of the Era of Society 5.0 can be considered as a society that has enjoyed the outcomes of the transformation of societal changes that occurred during the Era of Industry 4.0. The attitude taken and developed in this Era of Industry 4.0 will become the identity of each community group in the Era of Society 5.0. In the Era of Industry 4.0, people choose to be divided and easily provoked by various news that is present in the dynamics of society. There is a shift in the developed industry from creating hardware to a startup industry that is more dynamic and can reach all levels of society. The mobility that happens is no longer completely hindered by time and distance, but can shorten the time and provide efficiency in finding and conveying information with the presence of various communication media. Technological independence in the 
Era of Society 5.0 makes people have dynamic and widespread mobility and accessibility. This is as presented in Figure 2 in the application of technology in learning activities with QR Code access to share learning materials and other sources. This kind of access sharing has been broadly used because it is easier and works in a simple way.

Since the establishment of Industry 4.0, modern society has known the term "disruption" as part of the changes that have occurred in Industry 4.0. As a part of the developing modern culture, social media as a result of the development of knowledge has changed social relations from direct communication to communication using virtual media (Prasetyo \& Trisyanti 2018, Tambunan 2016, Zufar \& Sari 2021). Every change made by people certainly does not only generate a positive change, but also brings a negative impact along with it. The form of disruption that is present does not only affect the community in terms of culture shock with the shift of communication from direct to virtual communication media. The worse scenario can happen, particularly in terms of the facilitated provocation of hate speech through social media which is basically accessible to all users. People in the Era of Society 5.0 becomes very dependent on technology. There are several natural human abilities that no longer function optimally because they have been assisted by technological sophistication, such as direct verbal communication skills, the ability to think clearly, and good personal emotional control abilities. This happens because people in Society 5.0 have been comfortable being facilitated by technology that assists them. There is a paradigm shift in which communication and interaction with social media are easier and it provides convenience because of the time efficiency required. Meanwhile, the morality of humans as social beings who still require direct communication and interaction between humans is not fulfilled optimally. The passivity of the society generated in direct interaction and communication remains an unsolved problem.

\section{Perspectives of materialism and existentialism in the social sciences}

Modernization teaches that cultural development that is too focused on advances in the development of science and knowledge will not bring happiness to human civilization (Suriasumantri 2015). As seen in the problems that are emerged in the current society of Industry 4.0, advances in science and knowledge do not always bring all the conveniences. For example, the discovery of cloning techniques that were originally used in plant cultivation, is now started to be tested on humans. Even more, there are several unusual discoveries that are indeed beyond common human habits. The happiness of human civilization does not last long as the people who live in that civilization use science and knowledge to oppose their nature as humans. The war made by modern society is no longer a direct "duel" war; the ambition of a few people to dominate each other and dominate roles in the history of civilization in modern society makes them create new wars such as economic wars, bio-chemical weapons wars (nuclear and so on), as well as technological wars. Modern society is trapped in the problems caused by these wars. Science and knowledge that is developing rapidly and advancing have blinded the eyes of nature as social beings. This situation drives people to start thinking and acting rationally which influences the social paradigm of social changes that occur around them.

The act of rationality cannot indeed be separated from humans as an effort to achieve the desired goal (Budiardjo 2018, Soekanto 2015). Human sense leads to a framework of thinking based on causality that occurs from observations. When a plan that has been designed by humans goes well, they definitely will draw the conclusion that the view that is the basis of the plan drawn up is correct. Everything that exists is seen from what is visible and is measured by causality, that is the rationality of human beings. The will to achieve the desired goal makes them who think rationally forget some of the limitations that are actually their nature as social beings. The sense brings humans to be more absolute with the support of the science and knowledge they have. With the absolute power in humans, groups of people are formed consisting of those who have a strong ambition to create something new and produce a material that is able to satisfy the desire to fulfill their wishes. It is at this point that social thinkers review the views of groups of people that make problems in social stratification in society. 
Materialism can be considered as a form of excessive interest in money and material goods and considers these things to have a crucial role in life. This phenomenon has attracted the attention of philosophers and has been considered part of the negative side of human nature. Treating materialism as a psychological trait emerged in the 1990s. Psychologists tried to find a way to measure the level of materialism in a person (creating a psychological scale). Psychological research on materialism focused on an understanding of the roots of materialism (e.g., values, family, peers, and culture) and diagnosing its impact on human functioning (Kariarta 2020, Maison \& Adamczyk 2020). In the society of the Era of Industry 4.0, a materialism character has indeed been formed which is driven by demands to fulfill the needs and desires so that the mobility and accessibility of the community can run smoothly, easily, and efficiently in terms of time. The technology invented is certainly marketed at a high price. People become obsessed with having materials to buy these technological goods, thus a consumptive trend emerges in society. There is a view that if one does not have money, one will be left behind from social change in society. Materialism will form its own social stratification based on the material owned or produced by the community group. This grouping will later exacerbate social inequalities that occur in society. In fact, this may not be the case. People do need material and money to fulfill their needs and desires. However, if the desire for satisfaction does not interfere or can at least be controlled by them, it obviously does not make a significant social gap. Technology that is constantly changing and predicted as a high price as a result of the influence of the supply curve should not necessarily have an impact on the formation of the gap. However, the changing technology must be ensured that it can reach all levels of society and its convenience can be perceived by the broader community. Extensive skill development and character strengthening are also required to balance the negative effects of materialism. The $6 \mathrm{C}$ skills (Communication, Collaboration, Critical Thinking, Citizenship, Creativity, and Character) are needed in the society of Industry 4.0 to the Era of Society 5.0. These skills are still being developed to fulfill the needs of human resources that can balance the existing technological developments. This is as shown in the illustration in Figure 3 that society is becoming more consumptive as a result of the act of prioritizing contemporary lifestyles and trends. Eventually, they form their own social group with a social structure based on the ability to fulfill their material desires.

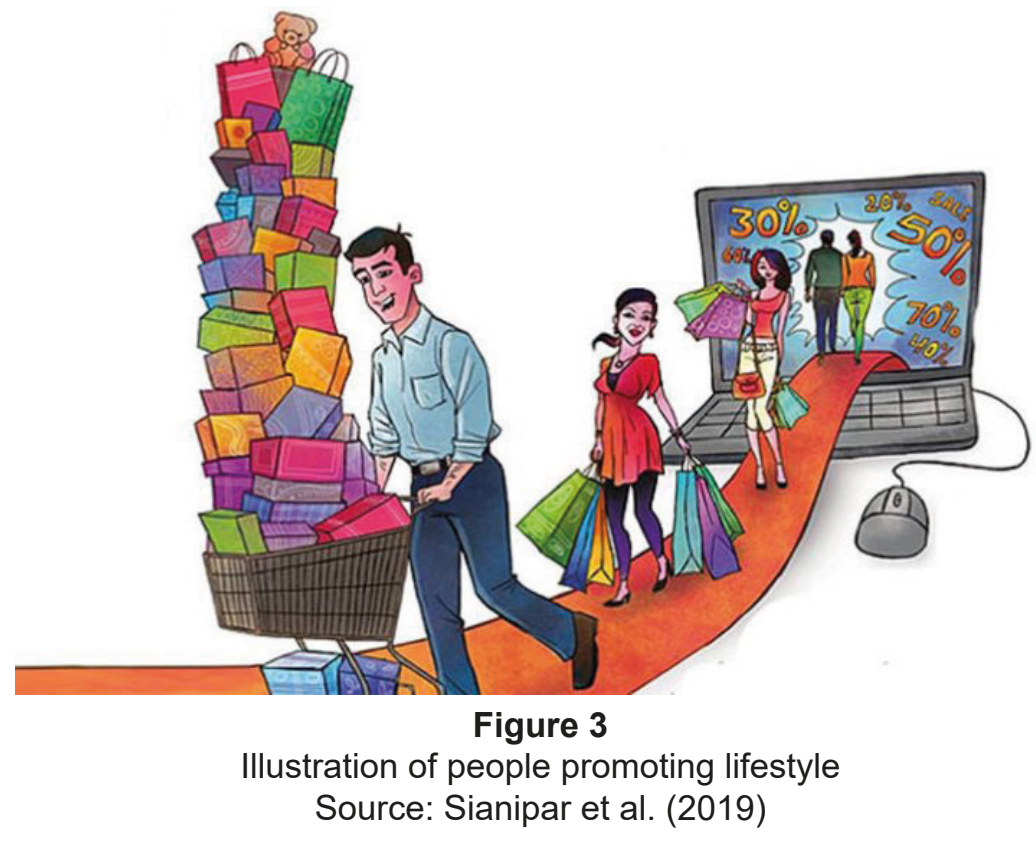

Humans have an existence that instinctively precedes their essence so that they have particular characteristics that make them different from other creatures. This is what drives them to create their own existence (Salim 2010, Syamsuddin 2005). The human urge to create is present as a result of sense reasoning science and knowledge. The development of science and knowledge is implemented in the form of technological products that are present today. Followers of existentialism think that every individual has the ability to create and stand alone in a responsible manner. The freedom to fulfill their 
needs is carried out by creating and transcending essence as something that is owned by every human being. With this perspective, a community group is formed that is always active in making technological innovations, but sometimes these innovations are intended for goals that have more negative impacts than positive ones. Existentialists believe that the art of creating is a form of self-actualization that shows the qualities of a human being. The impact is that the level of ambition to create an innovation turns into a competition for credibility and fame with innovations that actually go beyond human nature. The community becomes seen as arrogant with its abilities. The perceived freedom has made people feel they have power over everything they carry out. Absolute freedom makes its negative impact even more uncontrollable. As shown in Figure 4, the perspective of existentialism views people in the Era of Industrial Revolution 4.0. not only able to create the effectiveness of their mobility with the technology that was invented, but it also slowly creates their own social class based on the same idea of self-freedom.

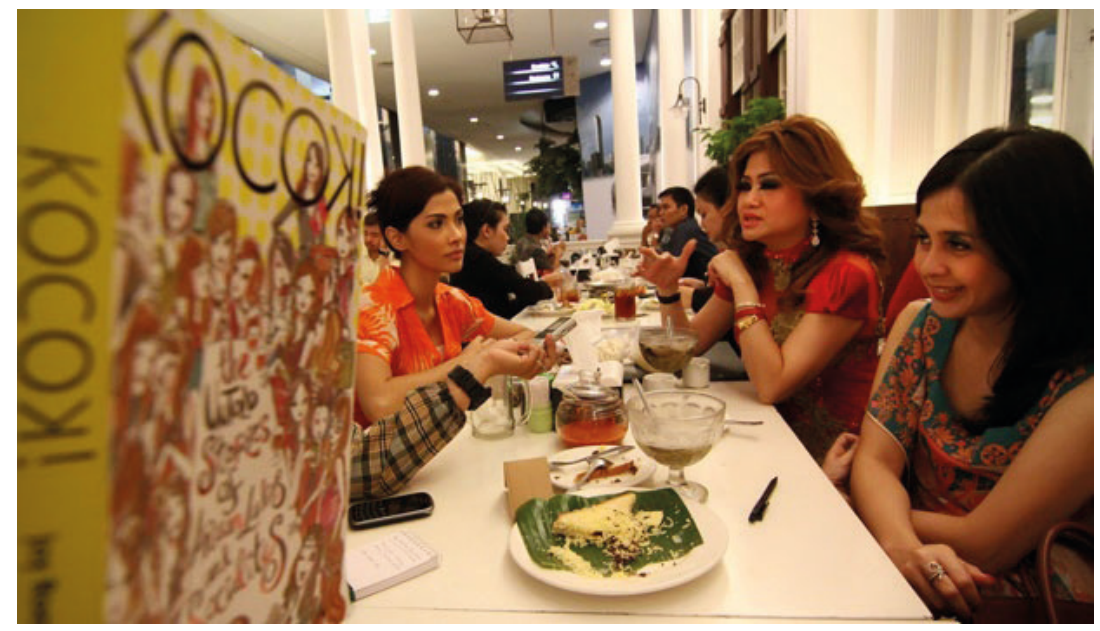

Figure 4

Socialite lifestyle in the Era of the Industrial Revolution 4.0

Source: Desyana (2013)

\section{The Era of Society $\mathbf{5 . 0}$ as the unification of humans and technology in the perspectives of materialism and existentialism}

The knowledge that grows with society and becomes part of social theory places knowledge at the main level and community groups are influenced by the results of the development of knowledge (Ritzer \& Smart 2018, Sindhunata 2020, Wankhede \& Vinodh 2021). The society in the Era of Industry 4.0 has proven that knowledge that grows together with the dynamics of society entering the disruption zone, presents a society that has high mobility and unlimited accessibility. The knowledge that is applied in the form of technological change makes people who live in that era have many conveniences, particularly in the tangible form that emerges, such as the number of smartphones produced with their respective advantages and other software, especially those that function as communication media, social media, and finance (m-banking \& internet banking). All data access is available in one single data which is commonly known as big data. Communication that is carried out no longer takes a matter of days, only a few seconds. To find out the distance traveled, address, and travel route, the information has now been presented digitally and can be accessed on a smartphone. When the Era of Society 5.0 will be operated, the dynamics of the existing society along with the technology that accompanies all its activities will be seen. The mobility and accessibility of society in this era is much higher and complex than those in the society in the previous era. Society in the Era of Society 5.0 has coexisted with developing technology. The dependency on technology is so great that several natural skills are fading away. This skill must be reactivated and upgraded. Until the society in the Era of Society 5.0, not only a society that has functional structural dynamics but also the technology is present to encourage the community massively to innovate with existing technology and be able to reduce the gaps that occurred in society. 
The science of reason knows that rationality indeed helps prevent humans from reasoning errors in searching for something that is not yet known (Khaldun 2011). The perspectives of materialism and existentialism do not present themselves, but the functional structural dynamics that occur in society make philosophers present a causal view of the phenomena that occur. Materialism views society in the Era of Society 5.0 as a time of increasing public desire for material ownership and money. The society in the Era of Society 5.0 becomes a society that creates its own social strata based on the amount of ownership of the material. Meanwhile, existentialism views society in the Era of Society 5.0 as a period of people's freedom to express and show their "self" to achieve everything they desire. Society in the Era of Society 5.0 is described as a society that is selfish, ambitious, individual, anti-social, even to the point of having a racist view (Małajowicz et al. 2019, Yaish \& Andersen 2012). An existence that is upheld beyond the essence of being a social being will form a system of society that has lost several of its nature as a social being. The society in the Era of Society 5.0 is able to reach a moment when society and technology are combined with each other. Society as technology users enjoys the convenience that is presented. As illustrated in Figure 5, developing technology has become a necessity for everyone. Remote communication and interaction can be facilitated by supporting social media. Sending letters is very easy only in a minute, entertainment is available with various kinds, transportation of goods can use robots.

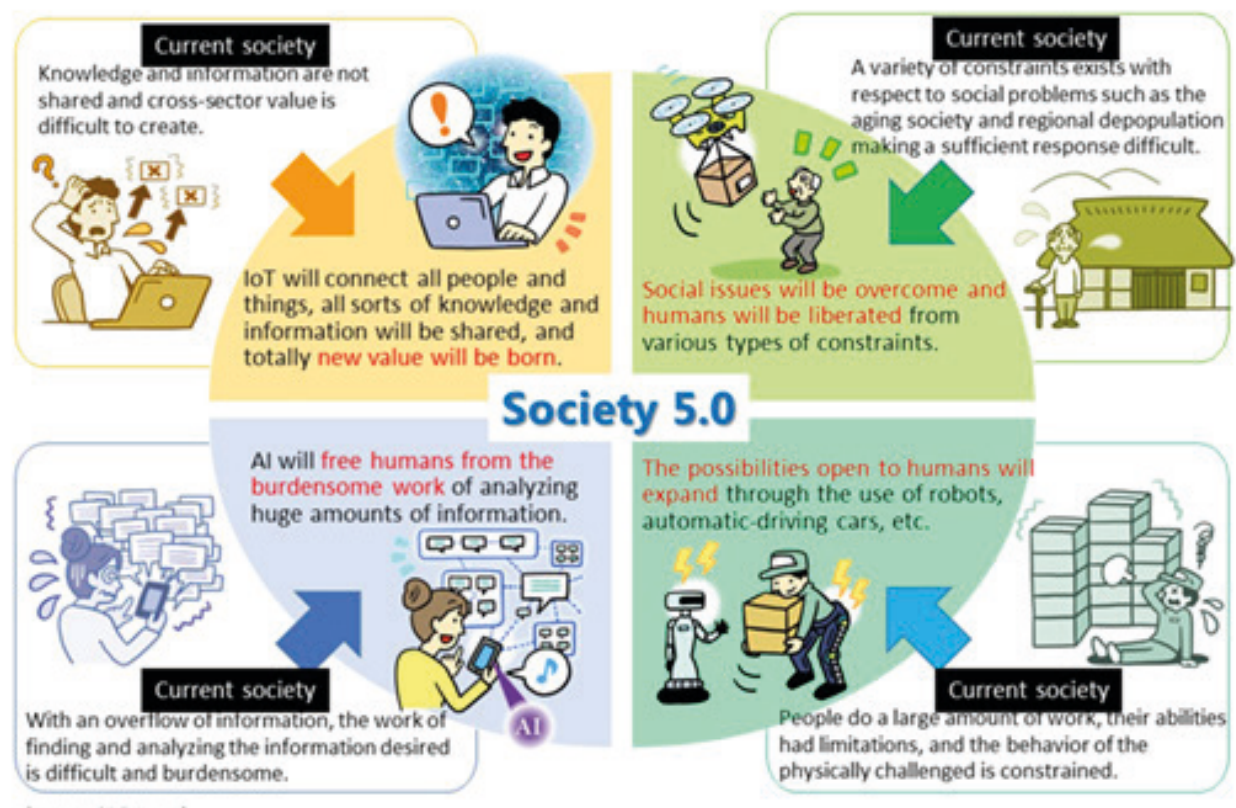

Figure 5.

Illustration of the convenience of society in the Era of Society 5.0 with the help of technology Source: Kristanto (2020)

Industry 4.0 provides all the necessary technologies to support human-machine interaction, with the functional purpose of reducing costs and increasing automated process control (Foresti et al. 2020, Ghobakhloo et al. 2021, Suwardana 2018). The shift of various activities from offline to online has encouraged updates from the Era of Industry 4.0. Digitalization in sustainable development goals supported by Artificial Intelligence (AI) makes this era of disruption has even more complex dynamics and problems. The society in the Era of Society 5.0 certainly experiences different dynamics and problems. As the final period of the transition of mobility and accessibility of society into technological devices, it presents a highly different situation. The society in the Era of Society 5.0 has been able to collaborate with technological devices and technological devices themselves have become a secondary need that is obviously fulfilled by all levels of society. Materialism in society in the Era of Society 5.0 can be avoided by making a transition in using technology devices as a secondary need of society. The stratification of society based on the material owned will not be formed because all communities can 
have the material in their own way to fulfill their needs. Existentialism in society in the Era of Society 5.0 can also not be formed because the community is almost entirely collaborating with each other. The 6C skills (Communication, Collaboration, Critical Thinking, Citizenship, Creativity, and Character) which used to be developed and encouraged to implement in the Era of Industry 4.0 have now entered and integrated into an individual of society in the Era of Society 5.0 as the identity of each individual and society in general. Materialism and Existentialism help provide an overview of the adverse effects of the dynamics and problems that occurs in society. Therefore, the causes of conflict in society can be minimized and people can live in harmony with the rolling modernity without forgetting their nature as social beings.

\section{Conclusion}

In the society in the Era of Society 5.0, technological progress is present maximally using smart systems. All technology devices have been designed and an innovative approach has been invented to managing data massively. The system created allows optimization of artificial logic networks and interactive process updates from community organizations. Interaction activities between humans and technologies are developed, adapted, and improved based on the needs of the time through effective management, ensuring the minimum deviation. The society in the Era of Society 5.0 lives in an order that is in line with the idea of globalization and the omission of waste in its various mobility. People in the Era of Society 5.0 indeed live in an integrated manner with technology. Thus, people in that era have a systemic order in a single data that is connected to all software that supported their activities.

The perspectives of materialism and existentialism provide a warning about the impact of the dynamics and problems that will be present in society in the Era of Society 5.0. The Era of Society 5.0 can certainly become a materialistic society if they are able to create a functional stratification of society based on ownership of materials. People in the Era of Society 5.0 can also become an existentialistic society if they form a competitive atmosphere resulting from their innovations to present a social conflict that has a broad impact. The $6 \mathrm{C}$ skills (Communication, Collaboration, Critical Thinking, Citizenship, Creativity, and Character) that were present before in the Era of Industry 4.0 helped encourage people in the Era of Society 5.0 to have a strong, innovative self-identity, and be able to make the technology present as an extension of the accessibility of modern society.

\section{References}

Arikunto S (2019) Prosedur Penelitian: Suatu Pendekatan Praktik. Jakarta: Penerbit Rineka Cipta.

Beltrami M, Orzes G, Sarkis J, \& Sartor M (2021) Industry 4.0 and sustainability: Towards conceptualization and theory. Journal of Cleaner Production 312:127733. https://doi.org/10.1016/J. JCLEPRO.2021.127733.

Budiardjo M (2018) Dasar-Dasar Ilmu Politik. Jakarta: Gramedia Pustaka Utama.

Desyana C (2013) Mengintip gaya foto sosialita saat arisan. Tempo.co, April 27. [Accessed 01 September 2021]. https://gaya.tempo.co/read/476239/mengintip-gaya-foto-sosialita-saat-arisan/ full\&view $=$ ok.

Ekawati D (2017) Eksistensialisme. Tarbawiyah: Jurnal Ilmiah Pendidikan 12 (1):137-153.

Foresti R, Rossi S, Magnani M, Guarino Lo Bianco C, \& Delmonte N (2020) Smart society and artificial intelligence: Big data scheduling and the global standard method applied to smart maintenance. Engineering 6 (7):835-846. https://doi.org/10.1016/J.ENG.2019.11.014.

Ghobakhloo M, Fathi M, Iranmanesh M, Maroufkhani P, \& Morales ME (2021) Industry 4.0 ten years on: A bibliometric and systematic review of concepts, sustainability value drivers, and success determinants. Journal of Cleaner Production, 302. https://doi.org/10.1016/J. JCLEPRO.2021.127052.

Jamwal A, Agrawal R, Sharma M, Kumar V, \& Kumar S (2021) Developing a sustainability framework for Industry 4.0. Procedia CIRP 98: 430-435. https://doi.org/10.1016/J.PROCIR.2021.01.129. 
Kariarta IW (2020) Paradigma materialisme dialektis di era milenial. Sanjiwani: Jurnal Filsafat 11 (1):71-81.

Kazancoglu Y, Sezer MD, Ozkan-Ozen YD, Mangla SK, \& Kumar A (2021) Industry 4.0 impacts on responsible environmental and societal management in the family business. Technological Forecasting and Social Change 173: 121108. https://doi.org/10.1016/J.TECHFORE.2021.121108.

Khaldun I (2011) Mukkadimah. Jakarta: Pustaka Al-Kautsar.

Koentjaraningrat (2015) Pengantar Ilmu Antropologi. Jakarta: PT Rhineka Cipta.

Kristanto A (2020) Society 5.0: Sebuah transformasi kehidupan masa depan. [Accessed 01 September 2021]. http://agungkristanto.ie.uad.ac.id/2020/02/society-50-sebuah-transformasi.html.

Mahmudi I (2019) Urgensi perilaku keagamaan pada era society 5.0. Prosiding Seminar Nasional Bimbingan Dan Konseling 3 (1):8-17.

Maison D \& Adamczyk D (2020) The relations between materialism, consumer decisions and advertising perception. Procedia Computer Science 176: 2526-2535. https://doi.org/10.1016/J. PROCS.2020.09.320.

Małajowicz AB, Zegleń P, \& Bernat T (2019) Knowledge and educational capital in the process of modern society creation. Procedia Computer Science 159: 2461-2469. https://doi.org/10.1016/J. PROCS.2019.09.421.

Meindl B, Ayala NF, Mendonça J, \& Frank AG (2021) The four smarts of industry 4.0: Evolution of ten years of research and future perspectives. Technological Forecasting and Social Change 168. https://doi.org/10.1016/J.TECHFORE.2021.120784.

Miles MB (1992) Analisis Data Kualitatif: Buku Sumber Tentang Metode-Metode Baru. Depok: Penerbit Universitas Indonesia.

Nagy K \& Hajrizi E (2019) Building pillars for adapting society 5.0 in post-conflict countries. IFACPapersOnLine 52 (25):40-45. https://doi.org/10.1016/J.IFACOL.2019.12.443.

Nakagawa EY, Antonino PO, Schnicke F, Capilla R, Kuhn T, \& Liggesmeyer P (2021) Industry 4.0 reference architectures: State of the art and future trends. Computers and Industrial Engineering 156. https://doi.org/10.1016/J.CIE.2021.107241.

Nastiti FE \& Abdu ARN (2020). Kajian: Kesiapan pendidikan Indonesia menghadapi era society 5.0. Edcomtech: Jurnal Kajian Teknologi Pendidikan 5 (1):61-66.

Prasetyo B \& Trisyanti U (2018). Revolusi industri 4.0 dan tantangan perubahan sosial. Prosiding SEMATEKOS 3 "Strategi Pembangunan Nasional Menghadapi Revolusi Industri 4.0," 0 (5):2227. https://doi.org/10.12962/j23546026.y2018i5.4417.

Putri VKM (2021) Dampak kemajuan teknologi di bidang sosial dan budaya. Kompas.com, September 04. [Accessed 01 September 2021]. https://www.kompas.com/skola/read/2021/04/09/142234669/ dampak-kemajuan-teknologi-di-bidang-sosial-dan-budaya?page=all.

Ritzer G \& Smart B (2018) Handbook Teori Sosial. Jakarta: Penerbit Nusa Media.

Salim I (2010) Aliran filsafat eksistensialis. Jurnal Pendidikan Sosiologi Dan Humaniora 1 (2):183-190.

Sallati C \& Schützer K (2021) Development of smart products for elders within the Industry 4.0 context: A conceptual framework. Procedia CIRP 100: 810-815. https://doi.org/10.1016/J. PROCIR.2021.05.039.

Sharma AK, Bhandari R, Pinca-Bretotean C, Sharma C, Dhakad SK, \& Mathur A(2021) A study of trends and industrial prospects of industry 4.0. Materials Today: Proceedings. https://doi.org/10.1016/J. MATPR.2021.04.321.

Sianipar CY, Junita M, Ananda NT, Pranata NFR, \& Dewi SP (2019) Diduga kaya, ternyata hanya gaya. Aceh Online, November 19. [Accessed 01 September 2021]. https://www.acehonline.co/feature/ diduga-kayaternyata-hanya-gaya/.

Sindhunata (2020) Dilema Usaha Manusia Rasional (Teori Kritis Sekolah Frankfurt). Jakarta: PT Gramedia Pustaka Utama.

Soekanto S (2015) Sosiologi Suatu Pengantar. Jakarta: Rajawali Press.

Suriasumantri JS (2015) Filsafat Ilmu: Sebuah Apresiasi terhadap Ilmu, Agama, dan Seni. Jakarta: Pustaka Sinar Harapan.

Suwardana H (2018) Revolusi industri 4.0 berbasis revolusi mental. JATI UNIK: Jurnal Ilmiah Teknik Dan Manajemen Industri 1 (1):109-118. https://doi.org/10.30737/jatiunik.v1i2.117. 
Syamsuddin M (2005) N. Driyakara SJ dan filsafat eksistensialisme. SOSIO - RELIGIA 4 (4):759-773.

Tabaa M, Monteiro F, Bensag H, \& Dandache A (2020) Green industrial internet of things from a smart industry perspectives. Energy Reports 6 (June):430-446. https://doi.org/10.1016/j. egyr.2020.09.022.

Tambunan SF (2016) Kebebasan individu manusia abad dua puluh: Filsafat eksistensialisme Sartre (freedom of human's individualism in the twenthieth century: Sartre's philosophy of existntialism). Jurnal Masyarakat \& Budaya 18 (2):215-232.

Wankhede VA \& Vinodh S (2021) Analysis of industry 4.0 challenges using best worst method: A case study. Computers and Industrial Engineering 159: 107487. https://doi.org/10.1016/J. CIE.2021.107487.

Yaish M \& Andersen R (2012) Social mobility in 20 modern societies: The role of economic and political context. Social Science Research 41 (3):527-538. https://doi.org/10.1016/J. SSRESEARCH.2011.12.001.

Zufar BNF \& Sari EK (2021) The other space of social media: Concept study of heterotopia on Instagram. Jurnal Sosiologi Dialektika 16 (1):12-23. 